\title{
PATTERNS OF SUSTAINABLE CONSUMPTION IN HIGH CONSUMPTION SOCIETIES. CASE OF POLAND
}

\author{
Felicjan BYLOK
}

Czestochowa University of Technology, Czestochowa, Poland

\begin{abstract}
The aim of this paper is to identify the patterns of sustainable consumption and the barriers that emerge during their implementation.

Methodology: The assumed aim was executed thanks to the application of the method of critical analysis of both national and international literary sources associated with sustainable consumption, while also the analysis of the findings of empirical research in the scope of occurrence of the patterns of sustainable consumption.

Findings: The findings of the empirical research indicate the relatively widespread application of the patterns of consumer behaviour that are characteristic of sustainable consumption on the part of consumers in Poland. Their dispersal is certified to by the increase in behavioural traits such as: the segregation of waste, the use of multi-use bags, partial restraint from driving cars, avoidance of the purchase of products that are harmful to the environment and the increase in the consumption of vegetables in the household. Barriers to its development would include the increasing use of utilities (electricity, water) in households, while also the increase in the indicator of motoring and the rising air pollution.

Research limitations: The research findings acquired, with regard to their varied nature (survey research, quantitative research) constitute the basis for limited conclusions.

Practical implications: The research findings provide knowledge on the magnitude of sustainable consumption and its barriers to development, which may serve the purpose of preparing new solutions in the policies of sustainable development.

Social implications: The research findings illustrated in this paper indicate changes in the attitudes of consumers with regard to the choice of products and the forms of consumption that are characteristic of sustainable consumption.
\end{abstract}

Key words: consumer behaviour, ecological consumption, sustainable consumption, sustainable development

JEL: E21, Q59

\section{Introduction}

In discussions about sustainable development, there are aspects related to alternative methods of consumption vs. the excessive consumption characteristic of a consumer society. One of them is sustainable consumption, which creates attitudes of consumer co-responsibility for the social and environmental effects of excessive consumption. The key idea of sustainable consumption is the pursuit of moderation in the purchase of new goods and consumption of products that do not damage the natural environment and the implementation of the goals of sustainable development, i.e. the principle of intra-generational and intergenerational justice. 
Sustainable consumption is one of the primary goals of sustainable development. It is often treated both as the core of sustainable development and a cross-cutting issue that is embedded in other goals of this development. In the context of sustainable development, the discussion on the need to change consumption towards consumption responsible for the natural and social environment is developing, which prompts the search for consumption patterns that could be promoted as important for the future.

The main goal of the article was to search for answers to research questions: What patterns of sustainable consumption occur in Poland? What are the barriers when it comes to their implementation? The assumed goal was achieved thanks to the use of the critical analysis method of the results of empirical research regarding sustainable consumption.

\section{Literature review- Sustainable consumption}

Sustainable consumption is an essential part of sustainable development. Its idea was developed in Agenda 21 documents (the proposed solutions covered promoting ecoefficiency and using market instruments to change consumption patterns), adopted by 179 countries during the Rio Earth Summit in 1992 (United Nations Conference on Environment and Development 1992). Sustainable consumption was first defined in the United National Environment Program (UNEP) as "the use of services and related products which respond to basic needs and bring a better quality of life, while minimizing the use of natural resources and toxic materials as well as emissions of waste and pollutants over the life cycle of the service or product so as not to jeopardize the needs of future generations" (Liu et al 2017, p.1). At the same time, there is no agreement when it comes to a precise definition of sustainable consumption, or even in terms of the scope of application of this concept. Researchers have different opinions in relation to sustainable consumption. The first group of researchers perceives it in a narrower context, i.e. consumer behaviour and lifestyle. For example, Seyfang (2009, p.3) defines sustainable consumption as "the consumption of more efficiently produced goods, and the 'green' and 'ethical' consumer is the driving force of market transformation, incorporating both social and environmental concerns when making purchasing decisions". The second group of researchers focuses on the broader context, concentrating on production processes and consumer goods, suggesting that the path to sustainable consumption leads mainly through more efficient, environmentally-friendly production and more sustainable products (Jackson 2007). The third group focuses on the impact of sustainable consumption on future generations. For example, the Oxford Commission on Sustainable Consumption (2000) defines sustainable consumption in terms of the ability of present and future generations to meet their tangible and intangible needs without causing irreversible damage to the environment or loss of function in natural systems. The fourth approach assumes that the most important 
goal should be ecological consumption. The key to its implementation is the growth of rational and ecologically-aware attitudes and behaviours based on deep values (Ottman 2003).

Various research perspectives can be found in the analyses of sustainable consumption. Some researchers focus on identifying factors influencing sustainable consumption, e.g. the impact of individual consumer behaviour on the quality of the natural environment (Liu et al., 2017; Wang et al., 2014). Some researchers perceive sustainable consumption as a form of anti-consumption (Black 2010), while others identify its practices with a "green" lifestyle (Gilg et al., 2005).

Due to the multi-dimensional aspect if this concept, sustainable consumption does not have unambiguously formulated indicators for its research. One of the proposed indicators for identifying the size of sustainable consumption is the set of indicators of sustainable consumption by Seyfang, (2009, p. 62), who listed localisation, reducing ecological footprints, community-building, collective action and building new infrastructures of provision. The purpose of localisation is supporting local businesses; eating more local, seasonal food to cut food miles; encouraging money to circulate locally; 'buy-local' campaigns; DIY, growing food on allotments. Reducing the environmental footprint of consumption can be achieved through shifting consumption to cut its social and environmental impact on others, to reduce the inequity of current consumption patterns; cutting resource use; demandreduction; carbon-reduction and low-carbon lifestyles. A local community can be built through the development of social networks around green building, local food, social volunteering; overcoming social exclusion barriers that make participation more difficult. Collective action can be developed by encouraging participation in local organizations; involvement in local government and public policy; generating critical mass to make new sustainable behaviours become the standard. New infrastructures of provision can be built through creating alternative food systems which avoid supermarkets; autonomous housing which doesn't rely on mains services; new systems of exchange.

Among the indicators described above, the ecological footprint of consumption deserves more attention, due to its importance in discussions on sustainable development. The purpose of the ecological footprint research is to compare actual consumption of renewable resources and services by people, and nature's supply of renewable such resources and services (Rees, Wackernagel 1996). Therefore, the ability of the Earth to regenerate, i.e. to restore the biological capacity of the environment (bio-capacity), is important. Bio-capacity acts as an ecological benchmark against which we can assess humanity's demand for natural resources for the biologically productive surface required to supply these resources and absorb waste (Galli et al., 2014). The value of the ecological footprint of consumption determines the area of biologically-productive area that is necessary to meet the vital needs of the human population, taking into account the lifestyle. The above makes it possible to determine whether the activities related to consumption are within the 
biological threshold defined by the biological capacity of the Earth (Lin et al., 2015). Thus, the ecological footprint as an indicator of sustainable consumption allows the assessment of the human pressure on the environment through the consumption of goods and services.

The implementation of the concept of sustainable consumption requires determination and many changes, which relate to such aspects as, determining the proportion between current and future consumption, optimizing satisfaction with consumption while maintaining an appropriate level of quality and usability of natural resources and the natural environment, fairly evenly distributed consumption among all people, establishing the right proportion between material consumption and meeting intangible needs.

\section{Methodology}

The research of sustainable consumption patterns in Poland consisted in the use of secondary analysis of existing quantitative data (desk research), which was used to investigate data contained in Eurostat reports, research institutions, author's own studies, and articles in scientific journals. As a result of the conducted research, some conclusions were drawn concerning the perspectives of sustainable consumption in Poland.

\section{Results}

One of the strategic goals of the implementation of sustainable development is to reduce waste by promoting appropriate consumption patterns and developing environmental awareness of the society. An important model of sustainable consumption is the reduction of municipal waste. The indicator of municipal waste generated per capita allows to monitor the negative impact of waste on the natural environment. Table 1 evidences that the amount of municipal waste generated per capita in Poland is relatively low compared to the EU average. The most waste per capita was generated by Denmark, Luxembourg, Cyprus and Germany. The least by Romania, Estonia, Poland and Slovakia. It can be concluded that the level of welfare affects the amount of waste. In high-income countries, the amount of waste is much higher than in low-income countries (Eurostat 2020).

Another pattern of sustainable consumption related to municipal waste is the segregation of household post-consumer waste. Research shows that $95 \%$ of Poles declare that their household rubbish is segregated (CBOS 2020). Similar results were also obtained in the author's research. Waste segregation (separation of glass, plastic, paper from the rest) is declared by 93\% of Poles (Bylok 2018). 
Table 1 Municipal waste generated in households per capita (kg)

\begin{tabular}{|l|l|l|l|l|}
\hline Year & Poland & EU & EU Max & EU Min \\
\hline 2010 & 316 & 503 & 696 & 305 \\
\hline 2013 & 297 & 481 & 747 & 272 \\
\hline 2016 & 307 & 489 & 815 & 307 \\
\hline 2019 & 336 & 502 & 844 & 280 \\
\hline
\end{tabular}

Source: data according to the Eurostat (2020)

The level of energy consumption in households is an important pattern of sustainable consumption. Power consumption by households includes all power consumption for space heating, water heating and all electrical appliances. An indicator of power consumption in households per capita was used in the study, which quantifies the consumption of power by households. The analysis of Table 2 shows that the indicator of power consumption per capita in Poland is more than 2 times lower than the EU average and more than 5 times lower than in Sweden, where consumption per capita was the highest.

One of the reasons for lower power consumption is the awareness of the need to reduce it. Surveys show that $90 \%$ of Poles declare limiting their power consumption. One way is to have energy-saving household appliances that are used (e.g. fridge, washing machine, etc.) (92\%). Another method is to turn off the TV, computer, radio from the power supply when not in use. Such action is taken by $58 \%$ of the respondents (CBOS 2020).

Table 2 Power consumption in households per capita

\begin{tabular}{|l|l|l|l|l|}
\hline Year & Poland & EU & EU Max & EU Min \\
\hline 2005 & 2.4 & 5.9 & 17.0 & 1.6 \\
\hline 2010 & 2.7 & 6.0 & 15.5 & 2.0 \\
\hline 2013 & 2.7 & 5.9 & 14.3 & 2.1 \\
\hline 2018 & 2,2 & - & 9.5 & 1,7 \\
\hline
\end{tabular}

Source: data according to Statistics Poland (2015), Electricity consumption per dwelling, https://www.odyssee-mure.eu/publications/efficiency-by-sector/households/electricity-consumptiondwelling.html

Responsibility for the natural environment also manifests itself in saving water. The analysis of the water consumption indicator per capita shows that that in Poland, on 
average, about 100 litres are consumed per capita per day, which is less than in Germany (123 1), Great Britain (167 1) or the Netherlands (132 1). However, more than Romania (85 1) (Statistics Poland 2020). Despite the lower rate in Poland compared to most EU countries, water consumption is at a high level. The analysis of research related to behaviour relating to saving water shows that the inhabitants of Poland point out that it is necessary to limit water consumption in their households. Such behaviour is undertaken by $89 \%$ of respondents (CBOS 2020). One way to reduce water consumption is to turn off the water tap while washing the dishes. This way of saving water is typical for 70\% of Poles (Bylok 2018).

Air pollution is an important indicator of the ecological footprint of consumption. One of its causes is the number and age of passenger cars. Passenger cars are a source of pollution, noise and waste. Limiting the use of passenger cars, especially older ones, in favour of public transport is an important model of sustainable consumption. In order to research this consumption pattern, the indicator of the share of the number of passenger cars by specific age groups in the total number of passenger cars was used (Table 3).

Table 3 Structure of passenger cars by age groups (\%)

\begin{tabular}{|l|l|l|l|l|}
\hline & 2011 & 2012 & 2013 & 2014 \\
\hline Up to 1 year & 2.5 & 2.6 & 2.5 & 2.6 \\
\hline $2-5$. & 8.3 & 7.7 & 7.0 & 6.4 \\
\hline $6-9$ & 12.0 & 11.8 & 11.8 & 11.6 \\
\hline $10-15$ & 31.4 & 29.2 & 27.4 & 26.2 \\
\hline $16-20$ & 9.6 & 10.8 & 11.6 & 12.0 \\
\hline 21 and over & 16.5 & 17.6 & 18.6 & 19.3 \\
\hline
\end{tabular}

Source: data according to the Statistics Poland (2015)

In Poland, the constant growth of cars older than 10 years is a negative phenomenon. Due to the solutions used, such cars have a negative impact on the condition and quality of the environment and road safety. Despite Poles declaring that they give up driving as much as possible and instead ride a bicycle, take the bus or train $(47 \%)$ (CBOS 2020), an increase in the number of registered cars is observed. Compared to 2018 , in 2019 there was an increase of $4.1 \%$ in the registered passenger cars and cars with a permissible total weight of up to 3.5 tons. Currently, 3.3 million trucks and 1,428,299 motorcycles are registered in Poland (Statistics Poland 2020).

Behaviour related to food consumption is a model of sustainable consumption. A responsible consumer makes an effort to limit meat consumption, due to the negative 
impact of breeding cattle, pigs and poultry on the production of greenhouse gas. In Poland, meat consumption has been growing gradually. The meat consumption rate per capita increased from $73.7 \mathrm{~kg}$ in 2010 to $77.1 \mathrm{~kg}$ in 2019. In particular, the consumption of beef increased by 58\%. Consumption of red meat per person amounted to $34.4 \mathrm{~kg}$ per capita in the household (Statistics Poland 2020) and is lower than the consumption of red meat in the EU, which ranges from $35.3 \mathrm{~kg}$ per capita per year in Bulgaria to $68.3 \mathrm{~kg}$ per capita per year in Spain. Average EU consumption of 57.6 kilograms per capita per year. As compared to consumers from other EU countries, where $6.2 \%$ gave up meat consumption and $35.4 \%$ reduced the consumption of red meat due to environmental protection in Poland only $8 \%$ of consumers significantly has reduced the consumption of meat (CBOS 2020).

Limiting meat consumption usually increases the consumption of vegetables. However, in Poland this dependence does not occur, because the consumption of vegetables has not increased for several years. The consumption rate per capita was $106 \mathrm{~kg}$ in 2019 and was $3 \mathrm{~kg}$ lower than in 2010 (Statistics Poland 2020).

A responsible consumer buys food products reasonably, i.e. only purchases those that are currently needed. In Poland 56\%, of respondents share the following opinion: "I buy as much food as I need without wasting any" (CBOS 2020). Other studies show that a quarter of Poles admit that in the last seven days their households have thrown food away; $7 \%$ say it happened several times, and almost every fifth person (19\%) believe it happened once in the last week. The most commonly thrown food products are vegetables and fruits (17\%), bread (17\%), leftovers from meals, i.e. leftovers from lunch, dinner (16\%) as well as cold cuts, meat and its products, e.g. cans, canned food (10\%) (CBOS 2016).

The potential of popularizing sustainable consumption patterns in Poland is evidenced by consumers' declarations that they pay attention to the ecological origin of products and the readiness to modify their purchasing habits, taking into account the idea of "sustainable consumption". In Poland, a relatively large percentage of consumers declare that they pay attention to eco-friendly origin when buying products (69\% of respondents). If we take into account the socio-demographic characteristics of consumers, men (71\%), aged 60 and more (81\%), with secondary education $(72 \%)$ pay attention to the eco-friendliness of products relatively more often. This attitude is least often displayed by young people aged 18-29 (64\%), with higher education $(65 \%)$. On the other hand, readiness to modify shopping habits, taking into account the idea of "sustainable consumption", is declared by $84 \%$ of Poles surveyed, while $46 \%$ of respondents definitely expressed such readiness. A detailed analysis of this indicator, taking into account the socio-demographic characteristics of the respondents, indicates that men are usually ready to modify their consumption behaviour in favour of sustainable consumption (51\% indicate definitely yes), aged 40-49 (51\%) and aged 18- 29 years (50\%), with higher education (52\%) (Bylok 2018). 
Generalizing the discussed research results, it can be concluded that the elements of sustainable consumption, i.e. the amount of electricity consumption, water consumption, the use of older cars, the amount of municipal waste negatively affect the ecological footprint of consumption in Poland. The analyses of the World Wide Fund for Nature (2016) show that the ecological footprint of Poland is on average $4 \mathrm{gha} /$ person, and the biological capacity is $2.1 \mathrm{gha} /$ person, which means that people in Poland use almost twice as much resources as the Earth could offer if everyone enjoyed its riches equally. In the ranking of OECD countries, Poland takes the 33rd place. Such a low position results from the fact that the combustion of coal and brown coal is used to a large extent to obtain power.

\section{Discussion}

Excessive consumption creates an ecological footprint of consumption which is relatively high in Poland (World Wide Fund for Nature 2016). Despite discussions on the need to reduce consumption in Poland and other EU countries, a continuous increase in the acquisition of products can be observed, e.g. EU household expenditure on household appliances increased by almost $30 \%$ in the years 1998-2008, whilst $80 \%$ of purchased appliances being thrown away when breaks down (Potočnik 2014). One way to reduce the ecological footprint of consumption is to promote the patterns of sustainable consumption. In Poland, there is an increase in the declarative use of sustainable consumption patterns, in particular the purchase of ecological products (CBOS 2020), which suggests that the awareness of social responsibility for the natural environment among consumers is spreading and affect the purchase and the use of environmentally friendly goods. However, when drawing conclusions from the research on sustainable consumption, one should take into consideration the discrepancies between the declarations and the actual consumer behavior. Carrington at al. (2014), focusing on these discrepancies between ethical intentions of consumption and actual behavior, found that embedded "unethical" shopping habits are multi-layered, associated with complex sequences of behavior, and therefore difficult to break. Similarly, the analyses of studies of environmental awareness as well as attitudes and behaviors of Polish consumers indicate significant discrepancies between consumer declarations reflecting high environmental awareness and readiness to pro-ecological behaviors and the actually undertaken behaviors (Rumianowska 2013). This situation also occurs in other EU countries (European Commission 2017).

Despite the discrepancies in the studies of behaviors characteristic of sustainable consumption, a conclusion can be drawn about its significant potential. This is particularly evident in highly developed countries, where the size of sustainable consumption and its market value volume are gradually increasing (Triodos Bank 2017). 


\section{Conclusion}

The research regarding the scope of sustainable consumption patterns in Poland shows that Poles declare their application in consumer behaviours in practice. This relates to behaviours associated with saving power, water as well as the production and segregation of post-consumer waste. The spread of consumption patterns related to eco-friendly products is visible to a large extent among older people, who have a great potential to change towards sustainable consumption. The ecological awareness of Poles is growing in favour of changing the patterns of consumption behaviour. Consumers declare that they pay attention to the ecological origin of products and express their readiness to modify their shopping habits, taking into account the idea of "sustainable consumption". However, the application of behaviour patterns related to the reduction of red meat consumption and collaborative consumption is not observed. The behaviour related to limiting the use of a passenger car in favour of public transport is also not noticed. Despite the declaration that they use this transport more and more often, the above is not confirmed by the statistical data. There are discrepancies between the declarations of the respondents and the statistical data.

\section{References}

1. Black I. (2010), Sustainability through anti-consumption, „Journal of Consumer Behavior”, vol. 9(6), pp. 403-411, doi:10.1002/cb.340

2. Bylok F. (2018), Konsumpcja zrównoważona jako element bezpieczeństwa, In: Sala K. (ed.) Polityka ekologiczna, pp.149-160,Wydawnictwo Naukowe Uniwersytetu Pedagogicznego, Kraków.

3. Carrington M.J., Neville B.A., Whitwell G.J. (2014), Lost in translation: Exploring the Ethical Consumer Intention-behavior Gap, "Journal of Business Research", vol. 67(1), pp. 2759-2768, doi.org/10.1016/j.jbusres.2012.09.022

4. CBOS (2016) Deklaracje Polaków dotyczące marnowania żywności, Komunikat $\mathrm{z}$ badań nr 115/2016, https://www.cbos.pl/SPISKOM.POL/2016/K_115_16.PDF (access: 15.05.2021).

5. CBOS (2020), Świadomość ekologiczna Polaków, Komunikat z badań nr 163/2020, https://www.cbos.pl/SPISKOM.POL/2020/K_163_20.PDF (access: 15.05.2021).

6. Electricity consumption per dwelling, https://www.odyssee-mure.eu/publications/efficiencyby-sector/households/electricity-consumption-dwelling.html (access: 17.05.2021).

7. European Commission (2017), Special Barometer, Attitudes of European citizens towards the environment. Survey requested by the European Commission, Directorate-General for Environment and co-ordinated by the Directorate General for Communication, http://mehi.hu/sites/default/files/ebs_468_en_1.pdf (access: 22.06.2021).

8. Eurostat (2020), Energy, transport and environment statistics, 2020 edition, Publications Office of the European Union, Luxembourg.

9. Galli A., Wackernagel M., Iha K., Lazarus E. (2014), Ecological Footprint: Implications for biodiversity, „Biological Conservation”, vol. 173, p. 121-132, doi: 10.1016/j.biocon.2013.10.019

10. Gilg A., Barr S., Ford N. (2005), Green consumption or sustainable lifestyles? Identifying the sustainable consumer, „Futures”, vol.37(6), pp. 481-504, doi: 10.1016/j.futures.2004.10.016 
11. Jackson T. (2007), Sustainable consumption, In: Atkinson G., Dietz S., Neumayer E. (ed.) Handbook of Sustainable Development, pp.254-271, Edward Elg Publishing Limited, Cheltenham, UK . Northampton, MA, USA.

12. Lin D., Galli A., Borucke M., Lazaru E., Grunewald N., Martindill, J., Zimmerman D., Mancini S., Iha K., Wackernagel M. (2015), Tracking Supply and Demand of Biocapacity through Ecological Footprint Accounting, In: Dewulf J., De Meester S., Alvarenga R.A.F. (eds.). Sustainability Assessment of Renewables-Based Products: Methods and Case Studies, pp. 179-200, Wiley, Hoboken, NJ, USA.

13. Liu Y.,Qu Y., Lei1 Z., Jia H. (2017), Understanding the Evolution of Sustainable Consumption Research, „Sustainable Development”, vol.25 (5), pp.414-430, doi: $\underline{10.1002 / \mathrm{sd} .1671}$

14. Ottman J.A. (2003), Green Marketing: Challenges and Opportunities for the New Marketing Age, NTC Business Books, Lincolnwood.

15. Oxford Commission on Sustainable Consumption (2000), Report on the Second Session of the Oxford Commission on Sustainable Consumption, OCSC 2.8, Oxford Centre for the Environment, Ethics and Society, Oxford.

16. Potočnik J. (2014), European Commissioner for Environment, We need a new revolution, „New Environmentalism Summit”, Brussels, No. 3 June, http://europa.eu/rapid/pressrelease SPEECH-14-424_en.htm (access: 18.06.2021).

17. Rees W., Wackernagel M. (1996), Our Ecological Footprint: Reducing Human Impact on the Earth, New Society Publishers, Vancouver.

18. Rumianowska I. (2013), Ekokonsumpcja jako warunek efektywniejszego wykorzystania zasobów przyrodniczych a świadomość $i$ zachowania konsumentów polskich, „Research Papers of Wrocław University of Economics“, No. 318, pp. 364-375; doi: $10.15611 / \mathrm{pn} .2013 .318 .35$

19. Seyfang G. (2009), The New Economics of Sustainable Consumption. Seeds of Change, Palgrave Macmillan, Houndmills, Basingstoke, Hampshire.

20. Statistics Poland (2015), Sustainable Development Indicators for Poland 2015, Katowice 2015.

21. Statistics Poland (2020), Statistical Yearbook of the Republic of Poland 2020, Warszawa.

22. Triodos Bank (2017), Ethical Consumer Markets Report 2017. http://www.ethicalconsumer.org/portals/0/downloads/ec\%20markets\%20report\%202017.pd f (access: 18.06.2021).

23. United Nations Conference on Environment and Development (1992), Report by the Director-General, World Health Organization Executive Board 12, https://apps.who.int/iris/bitstream/handle/10665/171232/EB91_Inf.Doc-5_eng.pdf (access: 18.06.2021)

24. Wang P, Liu Q, Qi Y. (2014), Factors influencing sustainable consumption behaviors: a survey of the rural residents in China, „Journal of Cleaner Production”, vol. 63, pp. 152-165, doi: $10.1016 /$ j.jclepro.2013.05.007

25. World Wide Fund for Nature (2016), Living Planet Report. Risk and resiliense in e new era, https://wwfint.awsassets.panda.org/downloads/lpr_2016_full_report_low_res.pdf (access: 18.05.2021). 